\title{
MIESTŲ IR RAJONŲ KREPŠINIO SPORTO MOKYKLŲ MOKSLEIVIŲ SOCIALINIŲ İŪDŽIŲ RAIŠKA
}

\author{
Šarūnas Šniras, Romualdas Malinauskas \\ Lietuvos kūno kultūros akademija, Kaunas, Lietuva
}

\begin{abstract}
Šarūnas Šniras. Socialinių mokslų daktaras. Lietuvos kūno kultūros akademijos Sporto pedagogikos ir psichologijos katedros docentas.
\end{abstract} Mokslinių tyrimų kryptis — moksleivių ir studentų socialinių igūdžių ugdymo ypatumai.

\section{SANTRAUKA}

Tyrimu siekta išsiaiškinti, kokie yra miestu ir rajonu krepšinio sporto mokyklų moksleiviu socialiniai igūdžiai. Moksline problema yra ta, kad dar stokojama žiniu, ar skiriasi miestu ir rajonu krepšinio sporto mokyklu moksleiviu socialiniu igūdžiu lygis. Tyrimo tikslas - atskleisti miestu ir rajonu krepšinio sporto mokyklu moksleiviu socialiniu igūdžiu raiškq. Kèlème hipotezę, kad miestu krepšinio sporto mokyklu moksleiviu socialiniu igūdžiu lygis yra aukštesnis.

Tyrimo metu buvo taikyti apklausos metodai. Esminiams socialiniams igūdžiams vertinti taikytas adaptuotas R. Riggio ir H. Friedman (1982) „Esminiu socialiniu igūdžiu klausimynas “. Vertinami šie socialiniai igūdžiai: emocinis ekspresyvumas, emocinis jautrumas, emociné kontrolè, socialinis ekspresyvumas, socialinis jautrumas ir socialine kontrolè. Situaciniams socialiniams igūdžiams vertinti taikytas E. Gambrill (1995) klausimynas (cituojama iš Hinsch, Pfingsten, 1998), kuri patys adaptavome. Adaptuotame klausimyne pateikti šie socialiniai igūdžiai: mokèjimas atsisakyti, reagavimas i pastabas, mokejjimas prieštarauti, atsiprašymas, pripažinimas klydus, mokèjimas džiaugtis būti pagirtam, pradèti pokalbi, mokèjimas pakalbèti, mokejjimas užbaigti pokalbi, paprašyti pagalbos, sakyti gerus žodžius, pasakyti kajauti.

Konstatuojamojo tyrimo metu naudojant atsitiktinès serijinès atrankos principq, sudaryta tiriamuju imtis iš miestu ir rajonu krepšinio sporto mokyklu 407 moksleiviu. Buvo tiriami 274 Kauno, Klaipėdos, Vilniaus miestu ir 133 Utenos, Jonavos, Anykščiu, Kauno, Biržu rajonu krepšini žaidžiantys moksleiviai.

Rezultatai parodè, kad rajonu krepšinio sporto mokyklu moksleiviu esminiai socialiniai igūužiai $(3,10 \pm 0,37)$ yra statistiškai patikimai $(p<0,05)$ aukštesnio lygio nei miesto moksleiviu $(2,98 \pm 0,47)$. Tyrimo rezultatai, be to, atskleidè, kad tam tikru esminiu socialiniu igūdžiu aukštesnis lygis yra būdingas rajonu krepšinio sporto mokyklu moksleiviams. Vis dèlto miestu ir rajonu moksleiviu vertinimas statistiškai nesiskyrè pagal šiuos situacinius socialinius igūdžius: mokèjimq atsisakyti, reaguoti i pastabas, atsiprašyti, pripažinima klydus, mokèjima džiaugtis pagirtam, pradèti pokalbi, pakalbèti, užbaigti pokalbi, paprašyti pagalbos. Tiek miestu, tiek rajonu 40—50\% moksleiviu šiu minètu situaciniu socialiniu igūdžiu lygi vertino kaip vidutinị.

Raktažodžiai: esminiai socialiniai ìgūdžiai, situaciniai socialiniai ìgūdžiai, krepšinio sporto mokyklos.

\section{IVADAS}

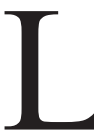
ietuvoje išsamiai nagrinejjami sportuojančių moksleivių doroviniai (Šniras, 2002; Šniras, Malinauskas, 2004, 2004 a), situaciniai (Šniras, 2004), varžybiniai (Šniras, 2005; Šniras, Malinauskas, 2006) ir esminiai (Šniras, 2001) socialiniai igūdžiai.

Atlikti konstatuojamojo (Šniras, 2002; Šniras, Malinauskas, 2004, 2004 a; Šniras, 2004) ir eksperimentinio (Šniras, 2005 a; Šniras, Malinauskas,
2006) pobūdžio tyrimai, taip pat tokie, kurių metu yra lyginami 10-12 ir 13-15 metų sportuojančių moksleiviu socialiniai igūdžiai. Vis dèlto trūksta mokslo darbų, kuriuose būtų nagrinėjami skirtingų regionų sportuojančių moksleivių socialinių igūdžių panašumai ir skirtumai. Šiuo tyrimu socialiniai igūdžiai apibrèžiami kaip adaptyvus ir adekvatus elgesys, padedantis įveikti kasdienio gyvenimo reikalavimus, pokyčius ir sunkumus (Argyle, 1996). 
Galima paminèti keletą užsienio autorių tyrimu (pvz., Grove et al., 1999; Sugiyama, 1999), nagrinejjančių šią problematiką. Lietuvoje tokių tyrimų trūksta, todèl būtina atkreipti demesi $\mathfrak{i}$ miestų ir rajonų krepšinio sporto mokyklų moksleivių socialinius igūdžius.

Žvalgomuju tyrimų rezultatai parodè, kad miestų (dideliu gyvenamujų vietovių) ir rajonų (nedidelių administracinių vienetų) moksleivių socialinis elgesys skirtingas, skiriasi ir šių tiriamuju grupių socialiniai igūdžiai (Madsen, 1975; Davidson et al., 1989; Meredith, Abbott, 1992; Blanton, Smith, 1993; Chithprabha, Kanekar, 1995; Chimonides, Frank, 1998; Young, 1998; Felton et al., 1999; Gibbs, 2000; Atav, Spencer, 2002; Cartwright, Allen, 2003; Pillay, 2003; Roberts et al., 2003). Kai kurių žvalgomujų tyrimų rezultatai rodo, kad miestų ir rajonų sportuojančių moksleivių socialinis elgesys taip pat skiriasi (Page, Tucker, 1994; Menifield et al., 2001; Loucaides et al., 2004). Visgi i klausimą, kaip skiriasi šių sportuojančių moksleivių socialinių igūdžių lygis (lygis čia suvokiamas kaip igūdžių, matuojamų balais, kokybès laipsnis), dar nėra atsakymo.

Prielaidą, kad miestų sportuojančių moksleivių socialiniai igūdžiai yra labiau išlavèję nei rajonų sportuojančiu moksleivių, galima grịsti panašiais tyrimais apie vaiku socializaciją (Kvieskienè, 2003) ir tyrimais apie gabių moksleivių socialinių igūdžių raišką (Narkevičienè ir kt., 2002). Būtų galima kelti ir papildomų klausimų: ar socialinių igūdžių stoka netampa itin didele rajonų moksleivių problema, nes juk paauglysteje iškyla daugybe klausimų tiek dèl socialinių sąlygų, tiek dèl psichosocialinių šio amžiaus pokyčių. Atsakymų i papildomus klausimus paieškoms reikètu išsamesnių tyrimų. Todèl šio tyrimo problemq apibrež̌ia toks klausimas: ar skiriasi miestų ir rajonu krepšinio sporto mokyklų moksleivių socialinių igūdžių raiška?

Nors pastarojo meto tyrimais (Vealey, 1988; White, 1993; Weinberg, Comar, 1994; Cox et al., 1996; Meyers, Bourgeois, 1999) nagrinėjami ìvairūs socialiniu igūdžiu tyrimo modeliai, tačiau šio tyrimo metu rèmėmès modeliu (Riggio, Friedman, 1982; Gambrill cituojama iš Hinsch, Pfingsten, 1998), kuris išskiria dvi socialiniu igūdžių grupes: esminius ir situacinius socialinius igūdžius. Esminiai socialiniai igūdžiai yra apibrěžiami kaip patys svarbiausi, reikalingi visomis gyvenimo situacijomis, susiję su žodinès ir nežodinès informacijos siuntimu ir prièmimu. Situaciniai socialiniai igūdžiai — tai igūdžiai, kurie dažniausiai sutinkami bendravimo ir bendradarbiavimo metu.

Tyrimo objektas - miestų ir rajonų krepšinio sporto mokyklų moksleivių socialiniai igūdžiai.

Tikslas - ivertinti miestų ir rajonų krepšinio sporto mokyklų moksleivių socialinių igūdžių raišką.

\section{Tyrimo uždaviniai:}

1. Palyginti miestų ir rajonų krepšinio sporto mokyklų moksleivių esminius socialinius igūdžius.

2. Palyginti miestų ir rajonų krepšinio sporto mokyklų moksleivių situacinius socialinius igūdžius.

Hipotezè. Keliama prielaida, kad miestų krepšinio sporto mokyklų moksleivių socialiniai igūdžiai yra aukštesnio lygio nei rajonų krepšinio sporto mokyklų moksleivių.

\section{TYRIMO METODAI IR ORGANIZAVIMAS}

Metodai: apklausa (adaptuotas R. Riggio, H. Friedman (1982) esminių socialinių igūdžių klausimynas); matematinè statistika (Stjudento $\mathrm{t}$ ir $\chi^{2}$ kriterijai).

Esminiams socialiniams igūdžiams vertinti taikytas adaptuotas R. Riggio, H. Friedman (1982) esminių socialinių igūdžių klausimynas. Vertinti šie socialiniai igūdžiai: emocinis ekspresyvumas, emocinis jautrumas, emocine kontrolè, socialinis ekspresyvumas, socialinis jautrumas ir socialine kontrolè.

Situaciniams socialiniams igūdžiams vertinti taikytas E. Gambrill (1995) klausimynas (cituojama iš Hinsch, Pfingsten, 1998), kurị patys adaptavome. Adaptuotame klausimyne pateikti šie socialiniai igūdžiai: mokejjimas atsisakyti, reagavimas i pastabas, mokejimas prieštarauti, atsiprašymas, pripažinimas klydus, mokejjimas džiaugtis būti pagirtam, pradèti pokalbi, mokèjimas pakalbèti, užbaigti pokalbi, paprašyti pagalbos, sakyti gerus žodžius, pasakyti ka jauti.

Abieju metodiku patikimumas ivertintas ir tinkamas moksliniams tyrimams (Šniras, 2005).

Tyrimo organizavimas. Konstatuojamojo tyrimo metu naudojant atsitiktinès serijinès atrankos principa, sudaryta tiriamuju imtis iš 407 miestų ir rajonų krepšinio sporto mokyklų moksleivių. Buvo tiriami 274 Kauno, Klaipèdos, 
Vilniaus miestu ir 133 Utenos, Jonavos, Anykščiuc, Kauno, Biržų rajonų krepšini žaidžiantys moksleiviai.

\section{REZULTATAI}

Analizavome miestų ir rajonų krepšinio sporto mokyklų moksleivių esminių socialinių ir situacinių socialinių igūdžiu lygị. Norint palyginti miestų ir rajonų moksleivių esminių socialinių igūdžių lygi, buvo apskaičiuoti šių igūdžių vidurkiai, standartiniai nuokrypiai, o skirtumo patikimumui nustatyti taikytas Stjudento $t$ kriterijus. Nustačius apibendrintą esminių socialinių igūdžiu indeksą, apskaičiavus visų šešių skaliu rezultatų vidurki matyti, kad rajonų krepšinio sporto mokyklų moksleivių esminiai socialiniai igūdžiai $(3,10 \pm 0,37)$ yra statistiškai patikimai $(\mathrm{p}<0,05)$ aukštesnio lygio nei miesto moksleiviu $(2,98 \pm 0,47)$ (1 lent.).

Tyrimo rezultatai taip pat atskleidè, kad tam tikrų esminių socialinių igūdžių lygis aukštesnis rajonų krepšinio sporto mokyklų moksleivių.

Paminètina, kad pagal emocini jautruma, socialini jautruma, socialinę kontrole rajonų ir miestu krepšinio sporto mokyklų moksleiviai patikimai skiriasi.

Nustatyta, kad rajonų moksleivių emocinio jautrumo įverčio vidurkis $(3,05 \pm 0,68)$ yra aukštesnis nei miesto moksleiviu $(2,84 \pm 0,73 ; \mathrm{p}<0,01)$. Didesnis socialinis jautrumas taip pat būdingas rajonų moksleiviams $(3,40 \pm 0,62 ; \mathrm{p}<0,01)$.

Palyginus miestu ir rajonu moksleiviu socialinès kontroles duomenis matyti, kad rajonu moksleivių rezultatu vidurkis $(3,54 \pm 0,62)$ yra aukštesnis nei miestų moksleivių $(3,37 \pm 0,76$; $\mathrm{p}<0,05)$. Tyrimas parodè, kad miestų ir rajonu krepšinio sporto mokyklų moksleivių emocinis ekspresyvumas, emocine kontrolè, socialinis ekspresyvumas statistiškai patikimai nesiskyrè.

Apibendrinant miestu ir rajonu moksleiviu esminių socialinių igūdžių lygio statistinius rodiklius galima teigti, kad rajonų moksleivių esminiai socialiniai igūdžiai yra labiau išlavejję.

Nustatydami miestų ir rajonų moksleivių duomenų skirstinio skirtumo patikimumą, taikème $\chi^{2}$ kriterijų. Tyrimo rezultatai rodo, kad miestų ir rajonu krepšinio sporto mokyklų moksleiviai statistiškai patikimai skyrèsi pagal šiuos situacinius socialinius igūdžius: mokèjima prieštarauti $(\mathrm{p}<0,05)$, sakyti gerus žodžius $(\mathrm{p}<0,05)$, pasakyti ka jauti $(\mathrm{p}<0,05)$ (2 lent.). Galima pažymėti, kad dalies situacinių igūdžių aukštesnis lygis būdingas miestų, o dalies - rajonų krepšinio sporto mokyklų moksleiviams. Pavyzdžiui, miestų moksleiviai mokejjimo prieštarauti (38\%) ir pasakyti kq jauti $(33,9 \%)$ igūdžiu lygi dažniau vertino kaip aukštą. 30,8\% rajonų moksleivių igūdžio mokèti prieštarauti ir $21,8 \%$ rajonų moksleiviu igūdžio pasakyti ka jauti lygi vertino kaip aukštą. Igūdi sakyti gerus žodžius kur kas aukščiau vertino rajonu moksleiviai $(36,8 \%$ rajonu ir 32,8\% miestu moksleiviu vertino kaip aukštą).

Vis dèlto miestų ir rajonų moksleivių vertinimai statistiškai nesiskyrè pagal šiuos situacinius socialinius igūdžius: mokejjima atsisakyti, reagavima i pastabas, atsiprašyma, pripažinima klydus, mokejima džiaugtis pagirtam, pradèti pokalbi, mokèjima pakalbèti, užbaigti pokalbi, paprašyti pagalbos. Tiek miestų, tiek rajonų 40$50 \%$ moksleivių šiu minètų situacinių socialinių igūdžiu lygi vertino kaip vidutini. Todèl galima daryti prielaida, kad îvairiomis gyvenimo ir sportinès veiklos situacijomis tiek miestu, tiek rajonų moksleivių elgesys nesiskirtu.

\begin{tabular}{|c|c|c|c|c|c|c|}
\hline Socialiniai igūdžiai & Vietové & $\mathrm{n}$ & $\mathrm{M}$ & $\mathrm{SD}$ & $\mathrm{t}$ & $\mathrm{p}$ \\
\hline Emocinis ekspresyvumas & Miestas & 274 & 2,35 & 0,60 & 0,971 & 0,332 \\
\hline & Rajonas & 133 & 2,29 & 0,64 & & \\
\hline Emocinis jautrumas** & Miestas & 274 & 2,84 & 0,73 & $-2,695$ & 0,007 \\
\hline & Rajonas & 133 & 3,05 & 0,68 & & \\
\hline Emocinė kontrolė & Miestas & 274 & 3,01 & 0,77 & $-0,717$ & 0,474 \\
\hline & Rajonas & 133 & 3,07 & 0,67 & & \\
\hline Socialinis ekspresyvumas & Miestas & 274 & 3,10 & 0,77 & $-1,389$ & 0,165 \\
\hline & Rajonas & 133 & 3,20 & 0,63 & & \\
\hline Socialinis jautrumas** & Miestas & 274 & 3,20 & 0,61 & $-3,161$ & 0,002 \\
\hline & Rajonas & 133 & 3,40 & 0,62 & & \\
\hline Socialiné kontrolé* & Miestas & 274 & 3,37 & 0,76 & $-2,393$ & 0,017 \\
\hline & Rajonas & 133 & 3,54 & 0,62 & & \\
\hline Esminių igūdžių indeksas* & Miestas & 274 & 2,98 & 0,47 & $-2,465$ & 0,014 \\
\hline & Rajonas & 133 & 3,10 & 0,37 & & \\
\hline
\end{tabular}

1 lentelè. Miestų ir rajonų krepšinio sporto mokyklų moksleivių esminių socialinių igū džių lygio statistiniai rodikliai

Pastaba. * - p $<0,05$, lyginant miestu ir rajonu krepšinio sporto mokyklų moksleivių rodiklių vidurkius. ** - p $<0,01$, lyginant krepšinio sporto mokyklų skirtingo amžiaus moksleivių rodiklių vidurkius. 
2 lentelè. Miestų ir rajonų krepšinio sporto mokyklų moksleivių pasiskirstymas pagal situacinių socialinių igūdžių lygi (skaičiais ir procentais)

\begin{tabular}{|c|c|c|c|c|c|c|c|c|}
\hline \multirow{3}{*}{ Socialiniai igūdžiai } & \multicolumn{8}{|c|}{ Lygis } \\
\hline & Vietovè & Žemas & & Vidutinis & & Aukštas & & $\chi^{2}(2)$ \\
\hline & & $\mathrm{n}$ & $\%$ & $\mathrm{n}$ & $\%$ & $\mathrm{n}$ & $\%$ & $\mathrm{p}$ \\
\hline \multirow{2}{*}{ Mokèjimas atsisakyti } & Miestas & 39 & 14,2 & 155 & 56,6 & 80 & 29,2 & \multirow{2}{*}{$\begin{array}{c}1,890 \\
\mathrm{p}=0,389\end{array}$} \\
\hline & Rajonas & 26 & 19,5 & 71 & 53,4 & 36 & 27,1 & \\
\hline \multirow{2}{*}{ Reagavimas it pastabas } & Miestas & 27 & 9,9 & 131 & 47,8 & 116 & 42,3 & \multirow{2}{*}{$\begin{array}{c}0,420 \\
\mathrm{p}=0,979\end{array}$} \\
\hline & Rajonas & 13 & 9,8 & 65 & 48,9 & 55 & 41,4 & \\
\hline \multirow{2}{*}{ Mokèjimas prieštarauti* } & Miestas & 31 & 11,3 & 139 & 50,7 & 104 & 38,0 & \multirow{2}{*}{$\begin{array}{c}8,165 \\
p=0,017\end{array}$} \\
\hline & Rajonas & 29 & 21,8 & 63 & 47,4 & 41 & 30,8 & \\
\hline \multirow{2}{*}{ Mokejjimas atsiprašyti } & Miestas & 53 & 19,3 & 113 & 41,2 & 108 & 39,4 & \multirow{2}{*}{$\begin{array}{c}2,209 \\
\mathrm{p}=0,331\end{array}$} \\
\hline & Rajonas & 31 & 23,3 & 45 & 33,8 & 57 & 42,9 & \\
\hline \multirow[b]{2}{*}{ Pripažinimas klydus } & Miestas & 43 & 15,7 & 115 & 42,0 & 116 & 42,3 & \multirow{2}{*}{$\begin{array}{c}0,362 \\
\mathrm{p}=0,835\end{array}$} \\
\hline & Rajonas & 24 & 18,0 & 54 & 40,6 & 55 & 41,4 & \\
\hline \multirow{2}{*}{ Mokejjimas džiaugtis pagirtam } & Miestas & 19 & 6,9 & 124 & 45,3 & 131 & 47,8 & \multirow{2}{*}{$\begin{array}{c}0,484 \\
\mathrm{p}=0,785\end{array}$} \\
\hline & Rajonas & 9 & 6,7 & 65 & 48,9 & 59 & 44,4 & \\
\hline \multirow{2}{*}{ Mokèjimas pradėti pokalbị } & Miestas & 75 & 27,4 & 124 & 45,3 & 75 & 27,4 & \multirow{2}{*}{$\begin{array}{c}1,105 \\
\mathrm{p}=0,575\end{array}$} \\
\hline & Rajonas & 31 & 23,3 & 67 & 50,4 & 35 & 26,3 & \\
\hline \multirow[b]{2}{*}{ Mokèjimas pakalbèti } & Miestas & 51 & 18,6 & 148 & 54,0 & 75 & 27,4 & \multirow{2}{*}{$\begin{array}{c}0,320 \\
\mathrm{p}=0,852\end{array}$} \\
\hline & Rajonas & 27 & 20,3 & 68 & 51,1 & 38 & 28,6 & \\
\hline \multirow{2}{*}{ Mokèjimas užbaigti pokalbi } & Miestas & 66 & 24,1 & 126 & 46,0 & 82 & 29,9 & \multirow{2}{*}{$\begin{array}{c}0,315 \\
\mathrm{p}=0,854\end{array}$} \\
\hline & Rajonas & 35 & 26,3 & 61 & 45,9 & 37 & 27,8 & \\
\hline \multirow{2}{*}{ Mokèjimas paprašyti pagalbos } & Miestas & 58 & 21,2 & 123 & 44,9 & 93 & 33,9 & \multirow{2}{*}{$\begin{array}{c}0,332 \\
\mathrm{p}=0,847\end{array}$} \\
\hline & Rajonas & 27 & 20,3 & 57 & 42,9 & 49 & 36,8 & \\
\hline \multirow{2}{*}{ Mokėjimas sakyti gerus žodžius* } & Miestas & 42 & 15,3 & 142 & 51,8 & 90 & 32,8 & \multirow{2}{*}{$\begin{array}{c}7,213 \\
\mathbf{p}=\mathbf{0 , 0 2 7}\end{array}$} \\
\hline & Rajonas & 8 & 6,1 & 76 & 57,1 & 49 & 36,8 & \\
\hline \multirow{2}{*}{ Mokėjimas pasakyti kąjauti* } & Miestas & 65 & 23,7 & 116 & 42,4 & 93 & 33,9 & \multirow{2}{*}{$\begin{array}{c}8,309 \\
p=0,016\end{array}$} \\
\hline & Rajonas & 46 & 34,6 & 58 & 43,6 & 29 & 21,8 & \\
\hline
\end{tabular}

Pastaba. * - p $<0,05$, lyginant miestų ir rajonų krepšinio sporto mokyklų moksleivių pasiskirstymą.

\section{REZULTATŲ APTARIMAS}

Atlikdami konstatuojamaji tyrimą, ypatinga dèmesi skyrème moksleivių socialinių igūdžių ir gyvenamosios vietovès priklausomybei tirti, o kitu socialiniu veiksniu neanalizavome. Taigi dabar ir apibendrinsime miestų bei rajonų krepšinio sporto mokyklų moksleivių socialinių igūdžių tyrimo duomenis.

Išanalizavus miestų ir rajonų moksleivių esminių socialinių igūdžių lygio statistinius rodiklius paaiškejjo, kad rajonų moksleiviu labiau išlavejję šie esminiai socialiniai igūdžiai: emocinis jautrumas, socialinis jautrumas, socialiné kontrolè. Būtu logiška daryti prielaidą, kad rajonų moksleiviai yra jautresni, nes miestuose pastaruoju metu yra didesnis susvetimejimas. Tyrimai, kuriais analizuojami miestų (didelių gyvenamujų vietovių) ir rajonų (nedidelių administracinių vienetų) moksleivių socialinis elgesys, rodo tam tikrus šių tiriamuju gru- pių skirtumus (Gibbs, 2000; Atav, Spencer, 2002; Cartwright, Allen, 2003; Pillay, 2003; Roberts et al., 2003). Vis dèlto minètu autorių darbuose analizuojamas ne sportuojančių moksleivių, o ịvairių socialinių grupių (neigalių, depresiškų, turinčių mokymosi sutrikimu) socialinis elgesys. Tuo tarpu kiti mokslininkai (Page, Tucker, 1994; Menifield et al., 2001; Loucaides et al., 2004) atskleidè miestų ir rajonų sportuojančių moksleivių socialinio elgesio skirtumus, tačiau ir jie negali būti interpretuojami kaip atitinkantys mūsų duomenis, kadangi tais tyrimais neanalizuojami esminiai socialiniai igūdžiai.

Išanalizavę miestų ir rajonų krepšinio sporto mokyklų moksleivių situacinių socialinių igūdžių duomenis galime pažymėti, kad tik tam tikros dalies situaciniu igūdžiu lygis aukštesnis miestų, o dalies - rajonų krepšinio sporto mokyklų moksleivių. Paaiškèjo, kad 50\% tiek miestų, tiek rajonų moksleivių situacinių socialiniu igūdžiu lygi vertino kaip vidutini. Todèl galima daryti prielaida, 
kad ịvairiomis gyvenimo ir sportinès veiklos situacijomis tiek miestų, tiek rajonų moksleivių elgesys nesiskirtų, o moksleiviai būtų vienodai jautrūs ir gebantys bendrauti, ir tai sutampa su kitu autoriu (Menifield et al., 2001) tyrimų duomenimis. Manome, kad šiuo tyrimu neatskleidème visų veiksnių, kurie turi itakos asmens elgesiui tam tikromis situacijomis. Kai kurie moksleiviai gali negebèti pasinaudoti turimais situaciniais socialiniais igūdžiais ir pasielgti netinkamai dèl daugelio kognityvinių, emocinių ir aplinkos sąlygų veiksnių, o kai kuriems gali iš viso trūkti tam tikrų situacinių socialinių igūdžių. Pavyzdžiui, sutrikusio intelekto jaunuoliai gauna daugiau teigiamų emocijų naudodami fizini smurtą, o ne tinkamus konfliktų sprendimo būdus. Kita vertus, pykčio ir neapykantos proveržio metu gali būti sunku tinkamai pasinaudoti turimais situaciniais socialiniais igūdžiais (Lochman, Dodge, 1994). Manome, kad mūsų tyrimo duomenis apie moksleivių situacinius socialinius igūdžius geriau paaiškina pastarasis teiginys - sportuojantys moksleiviai konkurencijos sąlygomis dažnai patiria neigiamų jausmų ir ne visuomet sèkmingai taiko turimus situacinius socialinius igūdžius.

Apibendrinus esminių ir situacinių igūdžių rezultatus galima teigti, kad rajonų krepšinio sporto mokyklų moksleiviai yra jautresni ir nuoširdesni, o miestuose pastaruoju metu yra didesnis susvetimèjimas.

Visgi būtų tikslinga atlikti išsamesnius tyrimus, kadangi gauti duomenys yra pagristi pačių moksleivių vertinimais. Galima būtų atlikti papildomus tyrimus ir jų metu taikyti stebejjimo bei ekspertu vertinimo metodus.

\section{IŠVADOS}

1. Rezultatai parodè, kad rajonų krepšinio sporto mokyklų moksleivių esminiai socialiniai igūdžiai yra statistiškai patikimai $(\mathrm{p}<0,05)$ aukštesnio lygio nei miesto moksleivių. Taip pat nustatyta, kad rajonų krepšinio sporto mokyklų moksleivių yra aukštesnis emocinio jautrumo, socialinio jautrumo bei socialines kontrolès socialiniu igūdžių lygis.

2. Tyrimu atskleista, kad miestų ir rajonų krepšinio sporto mokyklų moksleiviai statistiškai patikimai skyrèsi pagal šiuos situacinius socialinius igūdžius: mokejjima prieštarauti $(\mathrm{p}<0,05)$, pasakyti $k a$ jauti $(\mathrm{p}<0,05)$. Miestu moksleivių šiu situacinių igūdžių lygis aukštesnis. Sakyti gerus žodžius labiau $(\mathrm{p}<0,05)$ sekasi rajonų, o ne miestų krepšinio sporto mokyklų moksleiviams.

\section{LITERATŪRA}

Argyle, M. (1996). Social skills. In A. M. Colman (Ed.), Companion Encyclopedia of Psychology (pp. 454-465). London: Routlege.

Atav, S., Spencer, G. A. (2002). Health risk behaviors among adolescents attending rural, suburban, and urban schools: A comparative study. Family, Community Health, 25 (2), 53-64.

Blanton, P. W., Smith, D. J. (1993). Peer acceptance in middle childhood among rural and urban boys and girls. Journal of Genetic Psychology, 154 (2), 237-248.

Cartwright, F., Allen, M. (2003). Understanding the ruralurban reading gap. Education Quarterly Review, 9 (1), 9-18.

Chimonides, K. M., Frank, D. I. (1998). Rural and urban adolescents perceptions of menthal health. Adolescence, 33 (132), 823-832.

Chithprabha, K., Kanekar, S. (1995). A comparison of urban and rural students on scholastic and related variables. The Journal of Social Psychology, 135 (1), 117-118.

Cox, R. H., Liu, Z., Qiu, Y. (1996). Psychological skills of elite Chinese athletes. International Journal of Sport Psychology, 24, 326-340.

Davidson, Ph. M., White, P. N., Smith, D. J., Poppen, W, A. (1989). Content and intensity of fears in middle childhood among rural and urban boys and girls. Journal of Genetic Psychology, 150 (1), 51-59.

Felton, G. F., Parsons, M. A., Ward, D. S. et al. (1999). Tracking of avoidance of alcohol use and smoking behaviour in a fifth grade cohort over three years. Public Health Nursing, 16 (1), 32-40.

Gibbs, R. (2000). The challenge ahead for rural schools. Forum for Applied Research and Public Policy, 15 (1), $82-87$.

Grove, J. R., Norton, P. J, Van Raalte, J. L., Brewer, B. W. (1999). Stages of change as an outcome measure in the evaluation of mental skills training programs. The Sport Psychologist, 13, 107-113.

Hinsch, R., Pfingsten, U. (1998). Gruppenttaining sozialer Kompetenzen (3 Aufl.). Weinheim: Beltz.

Kvieskiene, G. (2003). Socializacija ir vaiko gerove. Vilnius: VPU.

Lochman, J. E., Dodge, K. A. (1994). Social-cognitive processes of severely violent, moderately aggressive, and nonaggressive boys. Journal of Consulting and Clinical Psychology, 62, 366-374.

Loucaides, C. A., Chedzoy, S. M., Bennett, N. (2004). Differences in physical activity levels between urban and rural school children in Cyprus. Health Education Research, 19 (2), 138-147. 
Madsen, M. C. (1975). Cooperation and competition of urban and rural children. International Journal of Psychology, 10 (4), 269-274.

Menifield, Ch. E., Rose, W. H., Homa, J., BreverCunningham, A. (2001). The media's portrayal of urban and rural school violence: A preliminary analysis. Deviant Behavior, 22 (5), 447-465.

Meredith, W. H., Abbott, D. A. (1992). Self-concept and sociometric outcomes: A comparison of only children and sibling children from urban and rural areas in the People's Republic of China. Journal of Psychology, 126 (4), 411-419.

Meyers, M. C., Bourgeois, A. E. (1999). Mood and Psychological skills of elite and sub elite equestrian athletes. Journal of Sport Behavior, 22 (3), 15-24.

Narkevičienè, B., Almonaitienè, J., Janilionis V., Rost, H. D. (2002). Itin gabiu vaiku ugdymo situacijos Lietuvoje analize. Kaunas: KTU.

Page, R. M., Tucker, L. A. (1994). Psychosocial discomfort and exercise frequency: An epidemiological study of adolescents. Adolescence, 29 (113), 183-191.

Pillay, A. L. (2003). Social competence in rural and urban children with mental retardation: Preliminarily findings. South African Journal of Psychology, 33 (3), 176-182.

Riggio, R. E., Friedman, H. S. (1982). The interrelationships of self-monitoring factors, personality, traits, and nonverbal social skills. Journal of Nonverbal Behavior, 7, 33-45.

Roberts, C., Kane, R., Thomson, H., Bishop, B., Hart, B. (2003). The prevention of depressive symptoms in rural school children: A randomised controlled trial. Journal of Consulting and Clinical Psychology, 71 (3), 622-630.

Sugiyama, Y. (1999). The effect of basic social skills and psychological competitive ability on competitive social skills. In the Dawn of the New Millennium. Proceedings of the 10th World Congress of Sport Psychology, Vol. 3 (pp. 81-82). Thessaloniki: Christodoulity Publications. Šniras, Š. (2005 a). Krepšinio sporto mokyklu moksleiviu socialiniu igūdžiu ugdymo ypatumai: daktaro disertacija. Kaunas: LKKA.
Šniras, Š. (2004). Krepšini žaidžiančių moksleivių situaciniai socialiniai igūdžiai trenerio ir komandos draugų akimis. Ugdymas. Kūno kultūra. Sportas, 2 (52), 79-84.

Šniras, Š., Malinauskas, R. (2006). Jaunųjų krepšininkų varžybinių psichologinių igūdžių lygio kaita dẻl ugdymo programos poveikio. Sporto mokslas, 2 (44), 31-36.

Šniras, Š., Malinauskas, R. (2004). Moksleivių dorovinių igūdžiu tyrimo ypatumai. Ugdymo psichologija, 11-12, 119-124.

Šniras, Š., Malinauskas, R. (2004 a). The peculiarities of moral skills of basketball-playing schoolchildren. In Sport Training in Interdisciplinary Scientific Research (pp. 279-284). Czestochowa: Faculty of Management Technical University of Czestochowa.

Šniras, Š. (2005). Ugdymo programos poveikis krepšini žaidžiančių moksleivių varžybiniams socialiniams igūdžiams. Ugdymas. Kūno kultūra. Sportas, 5 (59), 75-81.

Šniras, Š. (2002). Žaidžiančių krepšini moksleivių dorovinių-socialinių igūdžių ypatumai. Pedagogika, 58, 123-129.

Šniras, Š. (2001). Žaidžiančių krepšini moksleivių socialiniu igūdžiu svarba ir lygis. Sporto mokslas, 4 (26), $42-46$.

Vealey, R. S. (1988). Future directions in psychological skills training. The Sport Psychologist, 2, 318-336.

Weinberg, R. S., Comar, W. (1994). The effectiveness of psychological interventions in competitive sport. Sports Medicine, 18, 406-418.

White, S. A. (1993). The relationship between psychological skills, experience, and practice commitment among collegiate male and female skiers. The Sport Psychologist, $7,49-57$.

Young, D. Y. (1998). Rural and urban differences in student achievement in science and mathematics: A multilevel analysis. Scholl Effectiveness and School Improvement, 9 (4), $386-418$.

\title{
SOCIAL SKILLS IN SCHOOLCHILDREN OF URBAN AND RURAL BASKETBALL SPORTS SCHOOLS
}

\author{
Šarūnas Šniras, Romualdas Malinauskas \\ Lithuanian Academy of Physical Education, Kaunas, Lithuania
}

\begin{abstract}
This study is concentrated upon the investigation of schoolchildren of urban and rural basketball sports schools. Research, which analyse schoolchildren's social behaviour in towns (large populated localities) and regions (small administrative localities), shows certain differences between the tested groups according to social skills. Social behaviour of urban and regional exercising schoolchildren is different, too. However, there is no answer to the question how different the level of social skills in these groups of exercising schoolchildren is. The research aim is to reveal the peculiarities of social skills of schoolchildren in urban and regional basketball sport schools.
\end{abstract}


The following methods of research were applied: basic skills (emotional expressiveness, emotional sensitivity, emotional control, social expressiveness, social sensitivity, social control) inventory, situational skills (to be able to refuse, to react to remarks, to be able to contradict, to apologise, to accept being wrong, to be able to enjoy praise, to start a conversation, to be able to talk, to be able to end a conversation, to ask for help, to say good words, to tell what one feels) questionnaire, mathematical statistics (chi-squared test, $t$ test). By using the principle of random serial selection, the declarative research sample was constructed out of 407 schoolchildren of urban and regional basketball schools (including 274 children from urban and 133 children from regional basketball schools).

The results draw attention to the fact that basic social skills $(3.10 \pm 0.37)$ of schoolchildren in regional basketball schools are statistically significantly $(\mathrm{p}<0.05)$ higher than of urban schoolchildren $(2.98 \pm 0.47)$. Moreover, research results showed that higher level of certain basic social skills was characteristic of schoolchildren of regional basketball schools. Nevertheless, evaluations of urban and regional schoolchildren were not statistically different according to the following situational skills: ability to refuse, to react to remarks, to apologise, to accept being wrong, to be able to enjoy praise, to start a conversation, to be able to talk, to end a conversation, to ask for help. Forty to fifty percent of both urban and regional schoolchildren evaluated these social skills as average.

Keywords: basic social skills, situational skills, basketball sports schools.

\author{
Šarūnas Šniras \\ Lietuvos kūno kultūros akademija \\ (Lithuanian Academy of Physical Education) \\ Sporto g. 6, LT-44221 Kaunas \\ Lietuva (Lithuania) \\ Tel +37068346371 \\ E-mail SarunasSniras@one.1t
}

Gauta 2006 m. rugsèjo 1 d.

Received on September 1, 2006

Priimta 2006 m. gruodžio $6 \mathrm{~d}$.

Accepted on December 6, 2006 